\title{
Phaeochromocytoma and severe protracted postoperative hypoglycaemia
}

The postoperative management of phaeochromocytoma with special reference to glucose levels is discussed and precautions are elucidated.

On discute de la conduite postopératoire du phéochromocytome particulièrement concernant la glycémie, les précautions à prendre sont aussi considérées.

A phaeochromocytoma is a catecholamine-secreting tumour of the adrenal medullary cells of chromaffin origin. Approximately half of these patients are hyperglycaemic, ${ }^{1}$ and nearly 50 per cent require insulin. ${ }^{2}$ The management of phaeochromocytoma is by surgical excision of the tumour. The major intraoperative complications are severe hypertension, arrythmias and hypotension following removal, ${ }^{3}$

Postoperative hypoglycaemia is a rare complication. ${ }^{4}$ We report a case of protracted hypoglycaemia following surgical excision of a phaeochromocytoma.

\section{Case report}

A 26-yr-old female weighing $52 \mathrm{~kg}$ was admitted for investigation of intermittent hypertension (levels reaching $230 / 120 \mathrm{mmHg}$ ), headache, sweating and palpitations. A 24-hr urine specimen showed: vanillymandelic acid $50.8 \mathrm{mg} \cdot \mathrm{g}$ creatinine ${ }^{-1}(n=<6)$, metanephrine -28.4 $\mu \mathrm{g} \cdot \mathrm{ug}$ creatinine ${ }^{-1}(n=<2)$, free catecholamines -550 $\mu \mathrm{g} \cdot \mathrm{g}$ creatinine $\mathrm{C}^{-1}(n<70)$, blood sugar $125 \mathrm{mg} \cdot \mathrm{dl}^{-1}(n$ $\left.=80-120 \mathrm{mg} \cdot \mathrm{dl}^{-1}\right)$. Renal and thyroid function tests were within normal limits. The blood pressure (BP) was

\section{Key words}

COMPLICATIONS: coma, hypoglycaemia;

METABOLISM: hypoglycaemia;

SURGERY: phaeochromocytoma.

From the Department of Anesthesia and Intensive Care,

Lady Davis Carmel Hospital, Haifa, Israel.

Address correspondence to: Dr. H. Levin. controlled with alpha adrenergic blocking drugs (phentolamine $3 \mathrm{mg}$ IV twice daily for three days and subsequently phenoxybenzamine $40 \mathrm{mg}$ bid) and propranalol $40 \mathrm{mg}$ PO bid on the morning of the operation.

Premedication was with diazepam $10 \mathrm{mg} P O$ and meperidine $50 \mathrm{mg}$ IM one hour preoperatively. Prior to induction of anaesthesia the BP was $140 / 90 \mathrm{mmHg}$ and the heart rate was $80 \cdot \mathrm{min}^{-1}$. Cannulae were introduced under local anaesthesia into the radial artery and the superior vena cava. There was no change in the BP during cannulation. Fentanyl, $0.5 \mathrm{mg}$, and midazolam, $10 \mathrm{mg}$, were injected slowly and lidocaine, $100 \mathrm{mg}$, was given IV. Pancuronium, $6 \mathrm{mg}$, was injected to facilitate tracheal intubation and to maintain subsequent muscle relaxation. The lungs were ventilated by mask and after three minutes the trachea was intubated and the lungs were artificially ventilated. The $\mathrm{BP}$ increased to $230 / 120$ which was easily controlled with sodium nitroprusside $\left(1 \mu \mathrm{g} \cdot \mathrm{kg}^{-1} \cdot \mathrm{min}^{-1}\right)$. The right atrial pressure remained unchanged at $5 \mathrm{mmHg}$ throughout the procedure. Anaesthesia was maintained with a nitrous oxide/oxygen mixture (30 per cent) and 7 $\mu \mathrm{g} \cdot \mathrm{kg}^{-1}$ fentanyl. There were occasional minimal increases of BP and heart rate which were controlled by increasing the dose of sodium nitroprusside and small incremental doses of propranolol (total $2.5 \mathrm{mg}$ ). Intraoperative blood loss was approximately $1300 \mathrm{ml}$.

One unit of whole blood, one unit of plasma, $1000 \mathrm{ml}$ of Ringer's lactate and $1000 \mathrm{ml}$ of glucose five per cent were infused before removal of the tumour. The BP decreased immediately and the nitroprusside infusion was stopped. A further $1000 \mathrm{ml}$ of glucose five per cent and $1000 \mathrm{ml}$ of Ringer's lactate were infused.

The patient was transferred to the intensive care unit with her trachea intubated and breathing spontaneously. It was very difficult to arouse her in spite of painful stimuli. Her BP and heart rate were well maintained. Forty minutes after surgery she was still unrousable and it was suggested that this was due to fentanyl. She had received 7 $\mu \mathrm{g} \cdot \mathrm{kg}^{-1}$, but there was no respiratory depression. Blood gas analyses were within normal limits. A specimen of blood was sent for electrolyte and blood sugar estimation. Blood glucose concentration was $20 \mathrm{mg} \cdot \mathrm{dl}^{-1}$ with a 
normal electrolyte pattern. Glucose 50 per cent, $100 \mathrm{ml}$, was quickly infused via the central vein. Within two minutes she awoke and demanded that the tracheal tube be removed. The five per cent glucose solution was changed to ten per cent. Twenty minutes later blood glucose concentration was $276 \mathrm{mg} \cdot \mathrm{dl}^{-1}$. The patient was awake with normal cardiovascular variables.

One and a half hours after extubation it was noticed that the patient was again somnolent, did not obey commands, and responded poorly to painful stimuli. A blood sample was again withdrawn and $50 \mathrm{ml}$ of 50 per cent glucose was infused. The response was again dramatic. She awoke and her blood sugar concentration was found to be 40 $\mathrm{mg} \cdot \mathrm{dl}^{-1}$. The glucose ten per cent was changed to glucose 20 per cent solution and the rate of administration regulated to maintain a blood glucose concentration of 90 $\mathrm{mg} \cdot \mathrm{dl}^{-1}$. The following morning the 20 per cent solution was slowly reduced under laboratory control and by the evening she was able to maintain normal glucose levels without additional glucose. The patient was discharged from hospital eight days later, normotensive, normoglycaemic. Her VMA, metanephrine and free catecholamine levels had returned to normal.

\section{Discussion}

The catecholamines secreted by a phaeochromocytoma stimulate the alpha receptors of the pancreas and inhibit the release of insulin, ${ }^{5,6}$ so that there is a tendency to hyperglycaemia. Lipolysis is also stimulated by catecholamine secretion and there is a release of free fatty acids which contribute to the increase in blood sugar concentration by providing another source of energy and by decreasing the sensitivity to insulin. ${ }^{7-9}$ Surgical stress increases the release of diabetogenic substances: adrenocortical hormones, thyroid hormones and growth hormone. ${ }^{10.11}$

After excision of the tumour the catecholamine concentrations decrease rapidly and the hyperglycaemic effect disappears. It has been shown that after catecholamine infusions are suddenly stopped there is a marked increase in insulin output, ${ }^{12}$ with a tendency to hypoglycaemia. Propranalol with or without alpha adrenergic blocking agents may aggravate hypoglycaemia because of decreased sympathetic tone. ${ }^{13,14}$

Hypoglycaemia has been reported, though rarely, but there are no reports of protracted hypoglycaemia. Martin et al. ${ }^{15}$ reported a patient who responded immediately to a concentrated glucose infusion but did not have further relapses. Possibly one or a combination of the above explanations might have been the cause for the protracted hypoglycaemia in spite of 10 and 20 per cent glucose infusions.
Hypoglycaemia following excision of a phaeochromocytoma is a rare disorder. It may be fatal or may cause permanent brain damage if not detected early. Blood sugar concentration should be monitored during the operation and for at least $24 \mathrm{hrs}$ postoperatively. Portable, inexpensive glucometers are available for bedside monitoring.

\section{References}

1 Thorn GW, Adams RD, Braunwald E, Isselbacher KJ, Petersdorf $R G$. Principles of Internal Medicine, 8th ed., New York: McGraw-Hill, 1977; 560.

2 Sudre Y, Beck-Girandon B, Puoget-Abadie JF. Le diabéte du pheochromocytome. Sem Hop Paris 1976; 52: 1893-902.

3 Perry $L B$, Gould $A B J r$. The anesthetic management of pheochromocytoma: effect of preoperative adrenergic blocking drugs. Anesth Analg 1972; 51: 36-40.

4 Allen CTB, Imrie D. Hypoglycemia as a complication of removal of a pheochromocytoma. Can Med Ass J 1977; 116: 363-4.

5 Porte $D \mathrm{Jr}$. A receptor mechanism for the inhibition of insulin release by epinephrine in man. J Clin Invest 1967; 46: 86-94.

6 Cerasi $E$, Effendi $S$, Luft $R$. Role of adrenergic receptors in glucose induced secretion in man. Lancet 1969; 2 : 301-2.

7 Spergel G, Bleicher SH, Ertel NH. Carbohydrate and fat metabolism in patients with pheochromocytoma. $\mathrm{N}$ Engl J Med 1968; 278: 803-9.

8 Randle PH, Garland PB, Hales $C N$ et al. Glucose-fatty acid cycle: its role in insulin sensitivity and metabolic disturbance of diabetis mellitus. Lancet 1963; 1: 785-9.

9 Schlach DS, Kipnis DN. Abnormalities in carbohydrate tolerance associated with elevated plasma nonesterified fatty acids. J Clin Invest 1965; 44: 2010-3.

10 Goldenburg IS, Hayes MA, Greene NM. Endocrine response during operative procedures. Ann Surg 1959; 150: 190-5.

11 Greene NM, Goldenburg IS. The effect of anesthesia on thyroid activity in humans. Anesthesiology 1959; 20: 125-9.

12 Porte D Jr, Graber A, Kuzuya T et al. The effect of epinephrine on immunoreactive insulin levels in man. J Clin Invest 1966; 45: 228-36.

13 Shand DG. Drug therapy: propanolol. N Engl J Med 1975; 293: 280-5.

14 Skinner DJ. Uses of propanolol. N Eng! J Med 1975; 293: 1205.

15 Martin R, Bruno St-P, Quida-Ramon M. Phaeochromocytoma and postoperative hypoglycaemia. Can Anaesth Soc J 1979; 26: 260-2. 